\title{
Impact of Taxation on Economic Growth in an Emerging Country
}

\author{
Alaaeddin Al-tarawneh", Mohammd Khataybeh, Sami Alkhawaldeh \\ School of Business, University of Jordan, Amman, Jordan \\ Email address: \\ a.altarawneh@ju.edu.jo (A. Al-Tarawneh), khataybeh@ju.edu.jo (M. Kataybeh), samialameen@yahoo.com (S. Alkhawaldeh) \\ ${ }^{*}$ Corresponding author

\section{To cite this article:} \\ Alaaeddin Al-tarawneh, Mohammd Khataybeh, Sami Alkhawaldeh. Impact of Taxation on Economic Growth in an Emerging Country. \\ International Journal of Business and Economics Research. Vol. 9, No. 2, 2020, pp. 73-77. doi: 10.11648/j.ijber.20200902.13
}

Received: February 13, 2020; Accepted: February 25, 2020; Published: March 6, 2020

\begin{abstract}
Tax revenue and economic growth in Jordan have been undertaking an upward growth path in absolute terms. A number of studies indicated mixed results for the effect of taxes on economic growth. Numerous of these studies found a negative relationship, others found that taxes affect economic growth positively. So this paper trying to investigate the short and long run effects of taxation on economic growth in an emerging country, Jordan. Annual data for the time period $1980-$ 2018 used to develop an Auto-Regressive Distribution Lag (ARDL) approach. Results of the bounds test specify that the variables of economic growth, taxes, capital and trade are cointegrated. The empirical results of the estimated model confirm that there is a negative short and long run relationship between taxes and economic growth in Jordan. Also results of the cointegration estimation indicate that the short run deviations from long run equilibrium is adjusted by $60 \%$ towards long run equilibrium each year. Thus the paper proposes that fiscal policy is essential to promote sustainable economic growth. Therefore policy makers of the fiscal policy should take in account a tax rates that are appropriate to make enough revenues needed to finance government utility expenses that promote economic growth.
\end{abstract}

Keywords: Taxation, Economic Growth, ARDL, Co-integration, Jordan

\section{Introduction}

Governments play a crucial role in the country's economy, seeking to maintain and promote stability in both real and monetary sides. The cornerstone of stability is economic growth, which can be reflected by continues increase in total production in the economy. Theoretical literature stressed on government role through intervention by the main two policies; fiscal and monetary. For the fiscal policy, government expenditure and taxes, affects the output by influencing the aggregate economic activity. Where taxes can affect the growth through five ways; increase taxes can discourage investment rate, labor participation and hours of work, productivity growth, marginal productivity of capital, and distort the efficient use of human capital [1].

This led various studies to determine whether a long run relationship between taxation and economic growth exists. Most of the studies showed a negative relationship between two variables. As taxes increase, consumers will lose part of the purchasing power of their income, which made the demand curve to decline. In addition, producers will supply less, then a shift backward in the supply curve occurred. In total, the outputs will slowdown. In contrast, many studies (for example [2], [3], and [4]) found a positive effect of taxation on output.

Jordan economy has experienced a significant budget deficit for the last decade, so that total public revenue cannot cover public expenditure. Made the government depends on aids and taxes to overcome the deficit. Thus government continues the fiscal reform program headed for handling the budget imbalances. These procedures help to decrease the deficit to GDP ratio to $2.4 \%$ by the end of 2018 comparing with $8.3 \%$ of GDP in 2012. This decline caused by the increase in total public revenues (both taxes and non-taxes) greater than the increase of total expenditure. Where taxes revenue is calculated about $70 \%$ of total public revenue [5]. However, the public debt increased in 2018 to reach about $94 \%$ of GDP, generated by the obligatory funds needed to finance the budget [6]. On the other hand, growth rate in real terms did not go beyond $2.5 \%$ on average for the last ten 
years, not exceeds $2 \%$ in last couple of year.

Since the start of reform program in Jordan, tax revenue and economic growth have been undertaking an upward growth path in absolute terms. As the mixed results of number of studies for the effect of taxes on economic growth in Jordan, the main objective of this study to investigate the short and long run relationship between taxation and economic growth in Jordan for the time period 1980-2018 using an ARDL model.

The rest of this paper is organized as follow; section 2 reviews the literature of the relationship between taxation and economic growth. Section 3 represents the data and the model design. The followed section reports the results of the tests and empirical estimation. The last section concludes.

\section{Literature Review}

This section represents the key features of the empirical studies investigated the relationship between taxes and economic growth. Number of studies have examined the effect of taxation on economic growth. Findings of these studies were mixed; numerous consisted with the theory and found a negative effect for taxes on economic growth, however others confirmed a positive relationship between the two variables.

Scully, G. estimated the optimal tax rate that promote the economic growth for New Zealand. He found that decreasing the tax rate will increase the growth [7]. Lee Y. \& Gordon R. examined how tax policies can affect economic growth [8]. Findings proposed that statutory corporate tax rates are significantly negatively correlated with cross-sectional differences in average economic growth rate, so a cut in corporate tax rates by $10 \%$ leads to increase annual growth rates within countries by $1-2 \%$. Moreover, Arnold, J. investigated the effect of tax structure on aggregate economic growth for OECD countries [9]. Findings stressed on the negative effect of taxes on the economic growth.

In the same direction, Johansson A. \& others studied the design of tax structure which supports economic growth [10]. They found that corporate taxes are the most destructive for growth, followed by personal income taxes, and then consumption taxes. Another study for Padda I. \& Akram N. studied the impact of tax policies on economic growth for selected Asian countries; they found that changes in tax rate may have permanent effect on output and temporary effects on its growth rate. That any increase in tax reduces the level of output per capita, but no permanent effect on growth [11].

Dackehag M. \& Hansson A. explored the influence of income tax on economic growth for 25 rich OECD economies. Findings show that both taxation of corporate and personal income tax negatively affect economic growth [12]. Similarly, Macek, R. focused on evaluating the effect of each type of taxes on the economic growth for OECD's countries [13]. The study finds that both corporation rate taxation and personal income tax are critical for economic growth. Saqib S. \& others in turn examined the effect of taxation on the economic activity in Pakistan which measured through real GDP, consumption and investment [14]. They found that taxes negatively affect economic activity.

Zellner A. \& Ngoie K. investigated the effect of tax rate reduction on the US economic growth using a Marshallian macroeconomic model [15]. They found that a $5 \%$ cut in personal income and corporate tax rates will lead to about $3 \%$ increase in real GDP growth. Moreover, Dladla K. \& Khobai H. examined the effect of taxation on economic growth in South Africa. Using an ARDL approach, findings confirm the negative relationship between taxes and economic growth in South Africa [16]. Additional Mdanat M. \& others studied the impact of tax structure on economic growth in Jordan using error correction model [17]. Findings underline that income tax, corporate tax and personal income taxes negatively affect per capita income growth, when each one of them put in separate model. However the tariffs and consumption taxes have a positive effect. Recently Baiardi D. \& others investigated the relationship between tax policy and economic growth for OECD countries [18]. Findings emphasized a negative and significant relation.

On the other hand, empirical literature finds that some studies have a positive relationship between taxes and economic growth. Tosun M. \& Abizadeh S. studied the relationship between tax changes in OECD economies and economic growth [2]. The findings disclose that personal and property taxes have positive effect on growth of GDP per capita, while payroll and good and cervices taxes responded negatively.

Moreover, Kofi Ocran M. examined the impact of fiscal policy on the South Africa economy using a structural VAR model [3]. The findings show that tax revenue is positively correlated to output growth. Also Al-Shatti, A. investigated the effect of fiscal policy on economic development in Jordan using an OLS model [19]. Findings confirm a significant positive effect of current expenditure and tax revenues on economic development, conversely a significant negative effect of capital expenditure. Onakoya A. \& Afintinni O. examine the relationship between taxation and economic growth in Nigeria [20]. They found a significant long run positive effect of taxes on economic growth.

Babatunde O. \& others studied the effect of taxes on economic growth in Africa [4]. Findings indicate that tax revenue positively affects GDP and stimulates economic growth in Africa. Another study for-Stoilova D. focused on the relationship between tax structure and economic growth for 28 European countries using a pooled panel data [21]. The study found that selected taxes have a positive impact on economic growth. Additionally, Alkasasbeh O. \& others examined the effect of taxes and government expenditure on economic growth in Jordan [22]. Using an ARDL model, findings confirm a positive relationship between taxation and expenditure with growth.

Although, theoretical literature emphasizes a negative relationship between tax and economic growth, the results of the empirical studies are mixed. To sum up, there is no 
agreement on the link between taxation and economic growth because of the uncertainty of the relationship between these variables. This study thus uses ARDL approach to study the linkage between the two variables for the case of Jordan.

\section{Data and Methodology}

This study measures the impact of tax revenue on economic growth in Jordan, using annual data covering the time period 1980-2018. The source of the data of the variables is the World Bank database [23]. Table 1 presents descriptive statistics of the dependent and explanatory variables used in this study. GDP is the dependent variable $(L n Y)$, where Tax revenue ( $L n T x)$, a Trade indicator measured by the sum of export and import $(L n T r)$ and Capital measured by the fixed capital formation $(\operatorname{LnK})$ are independent variables, all are expressed in logarithm form.

Table 1. Descriptive statistics.

\begin{tabular}{lllll}
\hline & LnY & LnTx & LnTr & LnK \\
\hline Mean & 8.710 & 7.312 & 6.581 & 6.879 \\
Maximum & 10.272 & 8.578 & 7.964 & 8.376 \\
Minimum & 7.060 & 5.953 & 4.986 & 4.245 \\
Std. Dev. & 0.966 & 0.896 & 0.950 & 1.133 \\
Jarque-Bera & 2.324 & 2.857 & 2.665 & 2.330 \\
Probability & 0.313 & 0.240 & 0.264 & 0.312 \\
Observations & 39 & 39 & 39 & 39 \\
\hline
\end{tabular}

Following the literature of taxation and economic growth ([16], [17]), a model is considered to express the determinant function of the economic growth in Jordan, which could be stated as:

$$
\operatorname{Ln} Y_{t}=f\left(\operatorname{LnTx_{t}}, \operatorname{LnTr_{t}}, \operatorname{Ln} K_{t}\right)
$$

Following Pesaran H. \& Shin Y. and Pesaran H. \& others a general ARDL $(p, q)$ model can be presented as follows [24], [25], using the lag and first differences of the variables:

$$
\begin{gathered}
\Delta \operatorname{Ln} Y_{t}=\beta_{0}+\sum_{i=1}^{P} \beta_{i} \operatorname{Ln} Y_{t-i}+\sum_{j=i}^{q} \sum_{i=1}^{p} \delta_{j i} X_{j, t-i}+\sum_{i=1}^{p} \pi_{i} \Delta \operatorname{Ln} Y_{t-i}+ \\
\sum_{j=1}^{q} \sum_{i=1}^{p} \gamma_{j i} \Delta X_{j, t-i}+u_{t}
\end{gathered}
$$

Where $\Delta$ represents the first difference, and $p$ is the number of lags determined by information criteria, and $q$ is the number of independent variables, and $X_{t}$ denoted a vector of independent variables.

The application of this technique contains two steps. First one, test for the presence of cointegration relationship among dependent and independent variables by using the bounds test. The test's null hypothesis is no cointegration relationship among the variables. A computed $\mathrm{F}$ test gives two bounds, one based on the assumption that all variables in the ARDL model are cointegrated, and the other assumes that all variables are not. If the calculated $F$ is higher than the upper critical bound, then the null hypothesis is rejected, therefore a cointegration relationship between the variables exists. In the second step, if the long-run relationship exists, then the long-run and short-run coefficients of the equation (2) can be estimated.

Before we test for cointegration, the first stage in examining the long run relationship between the variables is to test whether the variables are stationary or non-stationary. To examine the non-stationarity feature of the series variables both on the level and in the first difference, the Augmented Dickey Fuller (ADF) test and Phillips Perron (PP) test ([26] and [27]) have been employed.

\section{Empirical Results}

\subsection{Unit Root Tests}

Results of the ADF and PP tests for stationarity are showed in Table 2. The t-statistics at level for variables GDP, trade and capital are less than the critical values at $10 \%$ level of significance for both ADF and PP tests. Where it is greater than $5 \%$ for tax revenue. This indicates that the null hypothesis of unit root hypothesis cannot be rejected for all variables except for tax revenue variable, implying that the three variables are non-stationary at level. However the null can be rejected on the first difference. So we can conclude that all variables can be cointegrated at the first difference, $I$ (1), except tax revenue which can be cointegrated at level, I (0).

Table 2. Unit root tests results.

\begin{tabular}{lllll}
\hline & ADF & PP & \\
\cline { 2 - 5 } & Level & 1st Difference & Level & 1st Difference \\
\hline LnY & 0.127 & $-2.751^{* * *}$ & -0.582 & $-5.077^{*}$ \\
LnTx & $-3.251^{* *}$ & & $-3.181^{* *}$ & I $(1)$ \\
LnTr & -1.042 & $-5.429 *$ & -1.018 & I $(0)$ \\
LnK & -0.537 & $-5.384 *$ & -0.653 & I $(1)$ \\
\hline
\end{tabular}

ADF, Augmented Dickey-Fuller; PP, Phillips-Perron; For critical values: 1\% -3.633, 5\% -2.948, 10\% -2.613.

*Significant at $1 \%, * *$ significant at $5 \%$ and $* * *$ significant at $10 \%$

\subsection{Bounds Test}

As variables cointegrated on deferent levels, $I(0)$ and $I$ (1), the ARDL approach is the appropriate model to be used. First the bounds test is implemented. The calculated $\mathrm{F}$ statistics is (5.27), which is greater than the critical values of the upper bound at 5\% significant level. This indicates that all variables are cointegrated, and there is at least one cointegration. Suggesting that there is a long run relationship between variables. Table 2 shows the results for the ARDL bounds test. 
Table 3. Bounds test results.

\begin{tabular}{llll}
\hline \multirow{2}{*}{ F statistic } & Critical values & \\
\cline { 2 - 4 } & Sig level & Lower bound & Upper bound \\
\hline \multirow{2}{*}{5.27} & $\mathbf{5 \%}$ & 3.23 & 4.35 \\
& $10 \%$ & 2.72 & 3.77 \\
\hline
\end{tabular}

\subsection{Results of the Long-run Estimation}

The results show that tax revenue have a negative and significant long run effect on economic growth. So a $1 \%$ increase in taxes is expected to decrease economic growth by $0.14 \%$. This result is consistent with findings of Mdanat M. $\&$ others which indicated that there is a long run negative impact of taxes on economic growth [17]. But in contradiction of both Al-Shatti A. and Alkasasbeh O. \& others who found a positive relationship between variables [19],[22]. The results also indicates a negative long run relationship between capital and economic growth. Results show that a $1 \%$ increase in trade is expected to raise economic growth by $1.5 \%$. However, a $1 \%$ increase in capital will decrease growth by $0.33 \%$. These results are in agreement with the findings of [16].

Table 4. Long-Run estimation results.

\begin{tabular}{ll}
\hline & Dependent variable: $\boldsymbol{L n} \boldsymbol{Y}$ \\
\hline LnTx & $-0.135(0.049)$ \\
LnTr & $1.460(0.000)$ \\
LnK & $-0.325(0.014)$ \\
Constant & $2.629(0.000)$ \\
\hline
\end{tabular}

\subsection{Results of the Short-run Estimation}

The impact of tax revenue on economic growth is found to be negative and significant in the short run. The short run results also show that trade openness have positive impact on economic growth and significant. The effect of capital on economic growth is positive but not significant. The estimated ECM (-1) is (-0.593), and significant. This result supports an existence of a long relationship among the variables. The results in Table 5 show that the ECM $(-1)$ is negative and significant at $1 \%$ level of significance. This result indicates that the short run deviations from long run equilibrium is adjusted by $59.3 \%$ towards long run equilibrium each year, thus it needs about a year and eight months to be adjusted. Table 5 represents the short run results.

Table 5. Ardl (1, 0, 4, 3) Cointegration estimation results.

\begin{tabular}{ll}
\hline & Dependent variable: DLn $\boldsymbol{~}$ \\
\hline DLnTx & $-0.080(0.067)$ \\
DLnTr & $0.248(0.003)$ \\
DLnTr $_{t-1}$ & $-0.277(0.004)$ \\
DLnTr $_{t-2}$ & $-0.108(0.288)$ \\
DLnTr $_{t-3}$ & $-0.165(0.029)$ \\
DLnK & $0.073(0.273)$ \\
DLnK $_{t-1}$ & $-0.045(0.490)$ \\
DLnK $_{t-2}$ & $0.104(0.105)$ \\
ECM $(-1)$ & $-0.593(0.000)$ \\
\hline
\end{tabular}

The diagnostic tests results are presented in Table 6. The first part of diagnostic tests is the test of normality and the results shows that the $\mathrm{p}$-value of Jarque-Bera is greater than $5 \%$, so this denotes that residuals are normally distributed. The p-value of the LM test for serial correlation also exceeds the $10 \%$ level means that it is insignificant, so there is no serial correlation. The Harvey test is used for heteroscedasticity; again the p-value is insignificant, which implies that there is no heteroskedasticity. Moreover Ramsey RESET test confirms the stability of the model.

Table 6. Diagnostics tests.

\begin{tabular}{ll}
\hline Normality test & $\mathbf{1 . 0 3 9}(\mathbf{0 . 5 9 5})$ \\
\hline Serial Correlation LM test & $0.419(0.663)$ \\
Heteroskedasticity test & $0.444(0.918)$ \\
Ramsey RESET test & $1.296(0.268)$ \\
\hline
\end{tabular}

\section{Conclusion}

This study investigates the impact of taxation on economic growth in Jordan for the time period 1980-2018. As the results of number of studies found a mixed effect of taxes on economic growth in Jordan ([17], [19], and [22]), this study comes to confirm the relationship among the variables using an ARDL approach. The bounds test confirms at least one cointegration exist. Results of the estimated model indicate that taxes affect economic growth negatively in the short and long-run. Furthermore results show a positive relationship between trade openness and economic growth again in the short and long-run. Conversely, results show a positive relationship between capital and economic growth in the shortrun only, but a negative relationship in the long-run. According to the results, it would be important to decrease taxes with the intention of increasing the economic growth in Jordan. Therefore government should make sure a tax rates that are appropriate to make enough revenue needed to finance government utility expenses that promote economic growth.

\section{References}

[1] Engen, E., \& Skinner, J. (1996). Taxation and economic growth. NBER Working paper series, No: 5826.

[2] Tosun M. \& Abizadeh, S. (2005) Economic growth and tax component: an analysis of tax changes in OECD, Applied economics, 37, 2251-2263.

[3] Kofi Ocran M. (2011) Fiscal policy and economic growth in South Africa, Journal of economic studies, 38 (5), 604-618.

[4] Babatunde O., Ibukun, A. \& Oyeyemi, O. (2017). Taxation revenue and economic growth in Africa, Journal of accounting and taxation, 9 (2), 11-22.

[5] Ministry of Finance (2018). Public finance monthly bulletin/ January. Amman, Jordan

[6] Central Bank of Jordan (2017). Annual report. Department of Research. Amman, Jordan

[7] Scully, G. (1996). Taxation and economic growth in New Zealand, Pacific Economic Review, 1 (2), 169-177. 
[8] Lee Y. \& Gordon R. (2005) Tax structure and economic growth, Journal of Public Economics, 89 (1), 1027-1043.

[9] Arnold, J. (2008). Do tax structure sffect aggregate economic growth? Empirical evidence from a panel of OECD countries, OECD Economic Development Working Papers, No. 643.

[10] Johansson, A., Heady C., Arnold J., Brys B. \& Vartia L. (2008) Taxation and economic growth, OECD Economic Development Working Papers, No. 640.

[11] Padda, I., \& Akram, N. (2009). The impact of tax policies on economic growth: Evidence from South-Asian economies. The Pakistan development review, 48 (4), 961-971.

[12] Dackehag M. \& Hansson A. (2012). Taxation of income and economic growth: An empirical analysis of 25 rich OECD countries. Lund University Department of Economics, Working Paper No 6.

[13] Macek, R. (2014). The impact of taxation on economic growth: Case study of OECD countries. Review of economic perspectives, 14 (4), 309-328.

[14] Saqib S., Ali T., Raiz M., Anwar S., \& Amir A. (2014). Taxation effects on economic activity in Pakistan. Journal of Finance and Economics, 2 (6), 215-219.

[15] Zellner A. \& Ngoie K. (2014) Evaluation of the effect of reduced personal and corporate tax rates on growth rates of the U.S economy, Econometric Reviews, 34 (1-2), 56-81.

[16] Dladla, K., \& Khobai, H. (2018). The impact of taxation on economic growth in South Africa. MPRA Working paper series, No: 86219.

[17] Mdanat, M., Shotar, M., Samawi, G., Mulot, J., Arabiyat, T. \& Alzyadat, M. (2018). Tax structure and economic growth in Jordan, 1980-2015. EuroMed journal of Business, 13 (1), 102127.
[18] Baiardi, D., Profeta, P., Puglisi, R., \& Scabrosetti, S. (2019). Tax policy and economic growth: does it really matter? International tax and public finance, 26 (2), 282-316.

[19] Al-Shatti, A. (2014). The effect of fiscal policy on economic development in Jordan. International business research, 7 (12), 67-76.

[20] Onakoya, A., \& Afintinni, O. (2016). Taxation and economic growth in Nigeria. Asian Journal of Economic Modelling, 4 (4), 199-210.

[21] Stoilova D. (2017). Tax structure and economic growth: Evidence from the European Union, Contaduria $y$ Administracion, 62 (3), 1041-1057.

[22] Alkasasbeh, O., Haron, N. \& Abueid, A. (2018). The impact of government expenditures, taxes on economic growth in Jordan. American based research journal, 7 (12), 32-38.

[23] World Bank (Jordan/ country profile) World Development Indicators, The World Bank Group. Retrieved from https://data.worldbank.org/country/jordan. Accessed 20/12/2019.

[24] Pesaran, M. H., \& Shin, Y. (1998). An autoregressive distributed-lag modelling approach to cointegration analysis. Econometric Society Monographs, 31, 371-413.

[25] Pesaran, M. H., Shin, Y., \& Smith, R. J. (2001). Bounds testing approaches to the analysis of level relationships. Journal of applied econometrics, 16 (3), 289-326.

[26] Said S. \& Dickey A. (1984). Testing for Unit Roots in Autoregressive Moving Average Models of Unknown Order. Biometrika. 71 (3), 599-607.

[27] Phillips P. \& Perron P. (1988), Testing for a unit root in time series regressions. Biometrica, 75 (2), 335-346. 